\title{
Secondary Teachers and Creativity in Teaching: Conceptions and Practices
}

\author{
Maria Mamoura (Corresponding Author) \\ Department of Philosophy, Pedagogy and Psychology, National and Kapodistrian University of Athens, Greece \\ Email: mmamoura@eds.uoa.gr
}

\section{Aglaia Raftopoulou \\ High School Teacher, Greece}

\author{
Article History \\ Received: March 21, 2020 \\ Revised: April 14, 2020 \\ Accepted: April 22, 2020 \\ Published: April 24, 2020 \\ Copyright (C) 2020 ARPG \\ \& Author \\ This work is licensed \\ under the Creative \\ Commons Attribution \\ International \\ (c) (1) $\mathrm{CC}$ \\ BY: Creative Commons \\ Attribution License 4.0
}

\begin{abstract}
In recent years, there seems to be a sharp shift towards the concept of creativity in education. Given that many theorists and researchers find it difficult to define the concept of creativity itself, this paper will attempt to investigate a) the conceptions about creativity in teaching of 5 teachers of humanistic subjects (Modern Greek Language, Ancient Greek Language, History, Greek Literature) in Greek secondary education b) how these specific conceptions are reflected in their teaching practices and c) the degree to which certain teaching strategies that seem to better facilitate creativity in teaching. The research data were collected from five (5) interviews, transcripts and worksheets of ten (10) teachings including field notes. Data were analyzed by the method of grounded theory. Data analysis showed that the emphasis is placed on "creative teaching" rather than on "teaching in order to develop student's creativity", as distinguished by Jeffrey and Craft. The most important finding of the research is that despite their good intentions or stated open perceptions, the research subjects do not systematically promote students' creativity unless they abandon their regulatory role and leave a genuine space of self-efficacy to their students. The authors conclude that further research is needed to answer the following questions: why is the model of creative teacher dominant and not that of the teaching that promotes students' creativity and in what extent and in which ways is creativity defined by specific cognitive subjects.
\end{abstract}

Keywords: Creative teaching; Teachers' conceptions; Students' creativity; Teaching practices.

\section{Introduction}

The invitations we face today are new. We are facing increasing pressure in all our areas of action. The new horizons of our lives require ingenuity, imagination, creativity. So, schools could be the place where new knowledge could be acquired and creatively could be built. But what kind of creativity do we need?

In recent years, the development of creative approaches in education and the activation of students' creativity through these approaches have gained the attention of the education world (Craft, 2005). Many theorists and researchers find it difficult to define the concept of creativity itself (Baker and Pomeroy, 2001; Friedel and Rudd, 2005). Although this term has been problematic (Cochrane et al., 2008; Craft, 2005), it is widely used to describe strategies and teaching approaches that involve students in meaningful learning and in developing productive and transformative behaviors (Sefton-Green, 2008). Creativity has been identified, inter alia, with divergent thinking (Dirkes, 1978; Torrance, 1977), the synthesis of knowledge, emotions/feelings and experiences (Sinnott, 1998), open mindedness/ thinking (Fasko, 2006), problem solving ability (Lewis, 2005; Ruscio and Amabile, 1999; Williamson, 2011), the creation of new, useful and valuable products, such as ideas, solutions or constructs (Ferrari et al., 2009; Kleiman, 2008; Lewis, 2005; Runco, 2008; Runco and Jaeger, 2012; Trana et al., 2017; Vygotsky, 2004; Williamson, 2011), assimilation and imagination (Piaget, 1962). It has also been argued that creativity can be developed with specific teaching strategies, as they all have the potential to be creative as well Lin (2011).

Creativity, therefore, is considered a dynamic process (Corazza, 2016), and is understood as an interaction between ability, process, and environment (Plucker et al., 2004). The process of creative thinking is thought to take place at different stages: finding a problem, incubating, lighting, controlling and spreading (Allen and Thomas, 2011). Also, students' thinking ability/possibility thinking (Craft, 2000) and creative learning (Jeffrey, 2006) are two other important elements of the term "creativity".

An important distinction used in our research is that of Jeffrey and Craft (2004) between "creative teaching", which focuses on using imaginative approaches in order to make learning more interesting and effective, and "teaching for creativity", which focuses on empowering students to develop their own creativity.

At this point, however, we cannot ignore a new view of creativity: one that derives from and is linked to economic growth and market values. Today, a dominant view, also linked to the concept of innovation, focuses on individual creativity, which fosters competitiveness, consumption, and success in the global marketplace. In this light, a variety of approaches such as sustainability, ethical foundations of creativity, and a collective perspective, 
namely the development of common goals (Claxton et al., 2008), seem to be marginalized. The repercussions of this dominant rationale for education appear to be quite serious, as it becomes natural, and it is not easy for teachers and students to discern, to put it in question and / or challenge it. Neither can the independence of their judgment be substantiated when it is not possible to ask the question: do we need the kind of creativity subject to the ubiquitous market discourse or a wise, humanitarian creativity (Claxton et al., 2008), that pays equal attention to goals and instruments/means?

The change comes from people involved in collective thinking processes and sharing common actions to develop imagination and new ideas of value to the wider community. Although the ideas of individuals contribute to the creative process, the progress of the whole is more than individual progress; it means that humanitarian creativity involves, among other things, the negotiation of others' needs and the building of an identity for the group (Chappell, 2008). In this sense, the concept of creativity is expanded and enriched.

\section{Research Questions}

Given that humanizing creativity is also geared towards students' empowerment, we consider that these two reasonings about the concept - humanizing creativity and teaching for creativity - are convergent. Based on this convergence, we decided to investigate how five Greek secondary teachers perceive and integrate the concept of creativity in teaching. The purpose of this research is, after having highlighted consistencies or inconsistencies between these teachers' conceptions and practices concerning creativity in teaching, to identify specific teaching practices and characteristics which could empower students to develop their own creativity.

Knowing teachers' conceptions about creativity in teaching can help us understand the needs and misunderstandings or even distinguish positive conceptions, which should be strengthened to enrich the field for decoding the concept of creativity as well as the conditions for its promotion in the classroom. On the basis of all the above, our research questions have been formulated as follows: a/ what are the conceptions of five (5) teachers about creativity in teaching, b/ how are these conceptions reflected in their teaching practices and c/which of these teaching strategies seem to mostly develop students' creativity.

\section{Research Methodology}

\subsection{Context and Participants}

We used the purposeful sampling technique to select our research subjects, as we wanted to select informationrich cases that could illuminate our research questions. We found it important to study cases that are rich in information, as they produce "insights and in-depth understanding rather than empirical generalizations" (Patton, 2015). Thus, five secondary teachers ( 3 female, 2 male) from four public high schools in Athens metropolitan area were the research subjects. They all are teachers of humanistic subjects (Modern Greek Language, Ancient Greek Language, History, and Greek Literature). The two common characteristics of the above teachers were: a/ they all collaborate with the Department of Philosophy, Pedagogy and Psychology (National and Kapodistrian University of Athens) as mentor teachers of undergraduate students and b/ they have similar backgrounds and experiences as they are highly qualified and have teaching experience of between eight and fifteen years in public education.

The data used in this study came from a variety of sources: a) direct observation of ten teachings in total (two teachings per research subject), b) five in-depth interviews by teachers, and c) worksheets given to students. Multiple methods of data collection methods were used to verify the accuracy of the data and to confirm the basic claims through triangulation (LeCompte and Preissle, 1993). The five teachers were informed about the context of our study and gladly accepted to participate.

\subsection{Data Analysis - Grounded Theory}

In order to answer the above research questions, data were analyzed using grounded theory method. The aim of this method is to create and formulate a theory based on empirical data, interpreting and stressing the most central idea that derives from them (Robson and McCartan, 2016; Strauss and Corbin, 1990). It is, therefore, an inductive approach through the systematic collection and analysis of data on the phenomenon under study (Strauss and Corbin, 1990).

In this research, the theory gradually emerged through the analysis of qualitative data and there was a constant dynamic interaction between data collection and the researchers' interpretation (Corbin, 2009). Initially, during the first phase of analysis, the open coding, we identified conceptual categories that emerged from the qualitative data, i.e. the data were subdivided into thematic areas, which were then categorized into specific conceptual categories (Robson and McCartan, 2016). In this particular case, open coding provided the four initial categories of teachers' perceptions and their corresponding - or no- teaching practices for creativity. In the second phase of analysis, the axial coding, through the correlation and interconnection of the initial categories, some conditions, strategies and consequences emerged as central and thus consolidated the central categories concerning the research questions (Corbin and Strauss, 1990). The two categories of axial coding refer to two different attitudes of teachers when they involve, as a goal, creativity in their teaching. Finally, during the third phase of analysis, the selective coding, the central conceptual core-category was more subtly highlighted (Robson and McCartan, 2016). 


\section{Results}

\subsection{Open Coding}

The open coding gave us four initial categories of teachers' conceptions and teaching practices about creativity: $\mathrm{a} /$ creativity in teaching is primarily a collective process that arises firstly from collaboration among students, $\mathrm{b} /$ creativity in teaching is associated with the creation of a communicative and relaxed atmosphere where students are free to express themselves without the fear of being wrong,

$\mathrm{c} /$ creativity in teaching is achieved when teacher uses analogies that link the teaching subject to real life, $\mathrm{d} /$ creativity in teaching is the use of imagination and the creation of a product facilitated by certain strategies.

\subsubsection{Creativity in Teaching as a Collective Process}

The subjects of the research highlight, through their own speech, the need of creating "a collaborative atmosphere" in order to foster creativity. A total of 14 references have been found in this category, which show that group collaboration: a. is preferred by students more than individual work, because "in the group they can more easily express their opinion, as it is combined with the opinions of others" and b. group collaboration is thought either as the ending of personal creativity ("First comes the motive of the individual, then all the creativities must be merged or combined") or as the condition for its evolvement ("In creativity it's good to share with your peers, to have someone by you that supports you. And then you can share your own piece of creativity").

These views about collectivity are captured 16 times during the teaching processes, as in most of them students worked in groups in order to share activities as instructed in worksheets that were given to them. Yet most of the activities were constructed in order to lead to predetermined answers, and did not encourage neither genuine collaboration nor the diversity and originality of students' answers in a way that could be seen as creative. An exception to the previous finding was the following teaching practice: during a Greek Language teaching about EU a coin of one euro was given to students' groups in order for them to observe and decide about its two sides and what is depicted on them. Students appeared, in this activity, to share diverse ideas and to negotiate other students' opinions in order to come to a conclusion about the need to compound different identities in EU. This could be seen as a creative collaboration which seemed to promote to some extent the creativity of students.

\subsubsection{Creativity in Teaching as a Creation of Communicative and Relaxed Atmosphere}

The second category includes the linking of creativity with freedom, communication, and the students' positive feelings. In this category we sorted 21 interviews extracts in total, which led to the following observations: Creative teaching takes place only in classrooms where real communication occurs. The value of communication is thought as really important, because creativity can be fostered only through the "proper teaching environment" and a good "educational relationship". The joy that comes out of the development of creativity is also central in the views of the individuals: the teachers' purpose is "the joy of creation", seeing "happy faces in the sad reality that surrounds us", since "students are happy when they are being creative". Students can gain self-esteem through creation, as "when they are creating, they feel better about themselves". That is why the teacher "must help students find their selfesteem" and "make them believe that they can learn". In creative teaching "the needs of the students, what they want from life, and their character" are well respected and expressed. In specific creative activities that are mentioned in their interviews, the teachers observed that "plenty of emotions were out in the open", as the students were free and fearless and thus expressed them openly.

In all ten (10) teachings of this research, we observed a rather greater correlation (than in the previous category) between teachers' perceptions and practices. We observed a really good communication environment, where students felt free to express their opinions, were smiling and seemed happy especially during the most creative moments of the teaching process. This class atmosphere was the result of the overall, spoken or unspoken, teachers' attitude towards their students and is clearly seen in shortcuts as the following: the students, during the study of the poem "Marina of the rocks" written by Odysseas Elytis ${ }^{1}$, are asked to imagine and write down an imaginative dialogue between the poet and Marina, the heroine of the poem, and to a student's question: "What you ask of us is a little poetic, isn't it?", the teacher responds: "If it comes out as a poem, I won't hold you back", liberating in this way the student(s) to make their choice about the form of their expression. A little later, during the same teaching, the teacher speaking about the last verse of the poem ${ }^{2}$ and its possible interpretations says "You can really say whatever you want to. Even I, who have read the poem plenty of times, believe a different thing each time about what Marina says farewell to". The creation of a communicative and relaxed atmosphere where students express themselves freely seems to promote the development of students' creativity, always in relation to the subject under teaching.

\subsubsection{Creativity in Teaching as the use of Analogies that Link the Teaching Subject to Real Life}

The third category includes teachers' conceptions about the need of finding analogies between the teaching object and students' lives, within the purpose of developing their creativity. A total of 10 references have been found in the teachers' own words and 6 references were found in teachings. More specifically: the teacher must find ways to "show the students that the lesson concerns them", "to show them that it is about their everyday lives", "to bring the lesson to their present" (even if it is about the past), because "whatever comes from the present and touches the

\footnotetext{
${ }^{1}$ Major Greek poet, awarded with the Nobel Prize for Literature in 1979

"'You will say farewell to the riddle that is yours"
} 
child can be creative". The process of linking the lesson with students' lives is done through the use of new technologies ("I'm editing photos, videos. I'm interested in animation, it is a challenge for me") and through the visualization of the information in digital or conventional ways ("work sheets", "dramatization", "videos"), so that "students are motivated to do something similar", as happened in an incident reported by one of the teachers of this research: students, after having followed a teaching of a syntaxis phenomenon with a fish that talked in a computer program made by the teacher, took the example, and in a following teaching session "constructed their own video and had ancient general Nikias talk and they really enjoyed it. We posted it online as well". Also, research participants speak about their students, who: "become more critical thinkers, finding on their own analogies/connections with the present and their own life", "interpretate the school object and reality itself in a creative way", and "find solutions about the problems of school material and the problems of life in a creative way". Therefore what teachers highlight is that an active attitude of students is a presupposition for creative understanding and dealing with reality.

These teachers' opinions are seen in plenty of teaching practices and activities during the teachings of this research, for example during a lesson of Kerkyraika by Thucydides, where the teacher used a front page about the war in Ukraine ("Tug of war of the forceful in the back of Ukraine") in order to make clear and to visualize the concept of a civil war. The teacher described to the students the play of "tug of war" and through this analogy with the present, the students seemed to understand in a better way the role that powerful countries' interests play in civil wars. In a similar way, during another teaching concerning the art of the Geometrical Era, students imagined the use of several objects of this period through the analogies with the present (skyfos=cereal bowl). These activities were interesting and helped students' understanding, but they were designed and transferred by the teacher in a traditional way, despite the use of new technologies or analogies. However, highlighting the analogies between school knowledge and the reality of the present seems to have developed, to some extent and despite the elements of teacher-centered teaching, some of the students' creative responses. As for the distinction used in our research (Jeffrey and Craft, 2004), this category reflects more on the concept of 'creative teaching' (imaginative approaches for more interesting and effective learning) rather than 'teaching for creativity', that is, the opening of perspectives for the development of students' creativity.

\subsubsection{Creativity in Teaching as Imagination and Creation of a Product}

The fourth category links creativity with students' imagination and the creation of a product facilitated mostly by dialogue or open semi-structured worksheets. Here we have two subcategories with 14 references in total in the teachers' speech and 10 in the teachings. For example, a teacher states: whoever is creative "that's why the purpose of a creative teaching is "for the students to reveal their imagination and aspects of their personality, which they hadn't realized they had". Creativity is linked with the creation of a product, since "whoever is creative, always makes new things", therefore, the aim is for the student "to create something all alone or with the others, after having heard other students' opinions and after seeing what his/her peers do". This product can take several forms: "it can be a really bright observation", "a construction of meaning", "some representation material", "an intervention that can lead to an overturn" (for example an activity about science and theatre, as described by one of the teachers) or a text in the form of creative writing activities (shift of the viewing angle, finishing the story, writing of a poem etc.).

The observation of the teachings confirmed the two subcategories: Initially, there were incidents where students were asked to use their imagination: ("Use your imagination!", "Sharpen your eyes and your mind"). As teachers meant what they were saying, the students used their imagination to some extent. Students' construction of meaning or product was translated into a series of clever observations during the dialogue but also through creative writing activities. For example, in a literature teaching of the poem 'Marina of the Rocks' by Odysseas Elytis they wrote a surrealistic poem, composed another poem using specific words from the original, created a poetic collage and gave their own interpretation of the poem by writing a fantastic dialogue between the poetic subject and Marina.

After the students created the poem collage based on three poems ${ }^{3}$, they seemed genuinely eager to read their version loudly and also to hear the version of others: "This was a great activity!", said one student at the end of the teaching. "Why do you think this is?" teacher asked. "Because it gave us the opportunity to use our imagination, but it wasn't difficult, as we had the poems in front of us," the student replied. The teacher took the chance and asked the whole class, "What do others think about what Alexis just said? Did you also enjoy this activity or not? ". The answers were positive. The students did enjoyed the activity and just the bell rang, one student said: "What was really great was that we realized we could all be creative. I was surprised by some of my classmates, and what they wrote. I didn't know they were so sensitive. And with myself of course ... ". Students seemed to open the boundaries of their subjectivity and enrich their understanding of themselves and the world.

During this teaching what was really obvious and different than in the other ones, was the fact that the teacher designed for the students activities that could lead to divergent answers and stepped back leaving them produce a really original work. In other words, the teacher in this case used semi structured worksheets, which did not require pre-determined student responses. So, in this two-hour teaching, students seemed to negotiate others' points of view and interpretations, and build, at the same time, a personal and collective identity, as they were involved in collective thinking processes. These characteristics are part of what is called humanizing creativity (Chappell, 2008). What is important is that the teacher of this lesson, during her interview, shared her belief that creativity is a capacity of all students, as long as one gives them the chance to express themselves: "You need to ask them the right question, to

\footnotetext{
${ }^{3}$ The other two poems that were studied in parallel with «Marina of the rocks» were «Dame de careau» by Paul Eluard and [Give me the tempest...] by Takis Sinopoulos.
} 
assign them an interesting and open activity, to let them speak freely and begin a dialogue, to really listen to them... The best part of a creative teaching is the moment where students, satisfied and sometimes surprised by themselves, share their creation with their classmates. It's the moment when creativities are in dialogue. And this is the moment when a transformation of former beliefs (about oneself, about the others, about life) can occur".

In terms of the distinction used in our research (Jeffrey and Craft, 2004), this category is probably the only one that mostly reflects the teaching of creativity, which does not focus on the teacher's imaginative techniques but on empowering students to developing their own creativity.

\subsection{Axial Coding}

In axial coding, we searched for conditions, strategies and consequences that emerged from research subjects' statements and practice as categorized above. The two categories of the axial coding refer to the attitudes and orientations of the subjects when they teach creativity. The first category highlights a type of teacher as regulator of the teaching process: It is about a teacher who encourages student collaboration and the correlation between the teaching object and real life (first and third category of the open coding). The fact that, despite their positive attitude towards creativity and their potentially imaginative practices, these teachers do not renounce the role of the teacher as regulator of teaching, it limits students' creativity to small, fragmentary events. The second category highlights a different type of teacher who leaves room for students; in a free, interactive context, he leads them with open-ended questions and activities to express themselves and develop their own creativity in the classroom (second and fourth category of the open coding).

\subsection{Selective Coding}

The correlation between the two core categories led us to the selective coding, where the central core category emerged which also holds the home of reasoning. This category is formed by all the correlations of the categories of open and axial coding categories, and can be worded as follows:

When the teacher has not actively questioned his or her regulatory role, then, as focused as he is on connecting school knowledge with real life and facilitating co-operation among students, his teaching cannot go beyond the boundaries of creative teaching, a teaching that makes learning partially more interesting and effective, but at the center of it remains the teacher himself. On the other hand, when the teacher, in a classroom where dialogue and open processes are prevalent, brings the students to the center of instruction, giving them space to express themselves and create their own discourse, their own texts or other products, then we can talk about a teaching for creativity, aiming at developing their own creativity. In other words, the difference lies in the extent to which teachers seem to give students time and space to express and create their own ideas, their own reason, or other products (Cremin et al., 2006).

\section{Discussion - Conclusion}

The main objective of this research was to investigate the conceptions of five (5) teachers on creativity in teaching, the ways in which these conceptions are reflected in their teaching practices and which of these teachers' strategies seem to mostly develop students' creativity. This research attempts to integrate and contribute to international research on creativity in teaching, giving new answers and creating new questions.

The most important conclusion of our research is that despite their good intentions or their stated open perceptions, the subjects of our research do not systematically promote students' creativity, unless if they renounce their regulatory role and leave an authentic space of self-efficacy to their students. When this is not the case, we can talk more about small, fragmented students' creative responses than about developing creativity.

On the other hand, when the regulatory role declines in favor of the space provided to students, all of the mentioned teaching strategies can, to some extent, promote students' creativity. Perhaps the most effective of all is the use of dialogue. Dialogue as a structured discussion between students and teachers, that can support a culture and a community of thinking and negotiating ideas and conflicts, has been mentioned by other researchers as a lever to promote productive-critical thinking (Gandini et al., 2005). Our research findings seem to extend this reasoning, highlighting the deeper implications of dialogue for students' creativity. When students engage in freer dialogue with their peers about literary texts, thus they are involved in collective processes that mobilize their thinking, they can further develop their imagination and produce original responses, new ideas and textual forms (creative texts), which seem to have value and stimulate the creativity of the wider community.

Another finding is that the type and format of the worksheet given to students, and whether the way the teacher uses it can limit or encourage students' creativity. A strictly structured teaching, using equally structured worksheets, seems to predetermine students' responses so that they can reach concrete conclusions without giving them the freedom to imagine and find alternative and authentic answers. According to relevant research findings, a condition necessary to promote students' creativity is the existence of a balance between structured and unstructured work (Halsey et al., 2006), as well as the pre-structuring of fully structured student work could be perceived as an emphasis on efficiency, which goes far beyond the consideration of creativity in humanities lessons. On the other hand, when the teacher uses semi-structured worksheets that do not require specific and predetermined answers, these responses do reflect both the personal thinking and imagination and the negotiation of the latter with the opinions of the classmates who became known in the free dialogue that preceded it. Students thus develop their creativity and build, at the same time, a personal and collective identity, which lies within the boundaries of humanitarian creativity (Chappell, 2008). Other researches have shown that creativity is related to a shift towards a 
less prescribed lesson plan in order to give more space to students' thinking and responses (Braund and Campbell, 2010; Cochrane and Cockett, 2007). According to our results, freer teaching lesson plan appears as the other side of the uneducated dialogue, and promotes creativity in conjunction with it. When the teacher provides freedom and confidence in communication in the classroom, when the questions he or she asks are open, and when he or she is open to the students' responses, he challenge them to produce, individually or collectively, original thoughts or works. Students become creative when they are free from the stress of measurable performance, and therefore from the experience of teaching forms that maintain that stress at the center.

Thus, we come to the next important finding: how teachers themselves do perceive their work is crucial to whether and to what extent students will develop their creativity. It is not enough for teachers to build close and warm relationships with students so that the latter feel free to express themselves through collaborative activities; nor is it enough for teachers to link school knowledge to students' present life, mainly through the use of analogies and new technologies (Cremin, 2009; Jensen, 1995). The latter are useful teaching strategies and are important factors in enhancing creativity in teaching, but they cannot independently develop students' creativity, especially when the teaching method is aimed at transferring knowledge and does not give students the initiative to think and act creatively. To be creative, students need to control and define their learning, take risks, make choices. Teachers could incorporate these capabilities into their teaching practice to "find a balance between freedom and structure that optimizes the potential for creativity" (Jónsdóttir, 2017), and to bring their teaching strategies to a permanent question (Morais and Azevedo, 2011).

The previous findings seem to confirm Jeffrey and Craft (2004) distinction between "creative teaching" and "teaching for creativity". The first is to use imaginative approaches to make learning more interesting and effective; therefore, it focuses primarily on the teachers' creative practices that lead to more effective teaching. The second, "teaching for creativity", focuses more on empowering students to develop their own creativity. According to the results of our research, although teachers in their discourse also refer to elements of their own creativity and to the elements necessary for the development of their students' creativity, the majority of teachings observed showed a significant tendency toward creative teaching, rather than the second element: few real opportunities were given to students to develop their creative potential, such as the authenticity of the answers, the imagination, the dynamic exchange of new ideas, the divergent thinking, and the creative failure, the transformative ability, and the production of new meanings and / or interpretations (Cranton, 2000; Danvers, 2003; O'Sullivan, 2002). At the same time, however, through real instructional snapshots (mainly through a two-hour literature teaching), some more effective teaching strategies for creativity emerged: a kind of dialogue that allows free and original responses as well as the use of semi-structured worksheets that allow for students' creative responses. This has led to another important question for further research: when creativity does not go beyond the curriculum as a whole, as Craft (2003) claims, and is not practiced interdisciplinarily, but within the limitations of distinct disciplines, as the Greek educational system does, then how strongly is it defined by the very nature of the subject itself?

\section{Limitations of the Research}

The limitations of our research include the small size of the sample and the limited number of teaching observations. The sample size and the qualitative characteristics of the data do not allow us to postulate generalibility; nevertheless there are important indicators and important questions that are raised about teachers' conceptions on creativity in the educational process and the ways in which students can be empowered to develop their creativity. Furthermore, students' perspective on the way in which they understand the concept of creativity and their sense of what constitutes a creative teaching are absent. The latter would be an interesting question for further research in this field.

\section{References}

Allen, A. P. and Thomas, K. E. (2011). A dual process account of creative thinking. Creativity Research Journal, 23(2): 109-18.

Baker, M. R. and Pomeroy, C. (2001). Relationships between critical and creative thinking. Journal of Southern Agricultural Education Research, 51(1): 173-88. Available: https://doi.org/10.1007/s11165-008-9110-0

Braund, M. and Campbell, B. (2010). Learning to teach about ideas and evidence in science: The student teacher as change agent. Research in Science Education, 40(2): 203-22. Available: https://doi.org/10.1007/s11165008-9110-0

Chappell, K. (2008). Towards humanizing creativity? Unesco observatory. Journal of Multi-Disciplinary Research in the Arts, 1(3): 1-22. Available: http://oro.open.ac.uk/37496/1/Towards\%20HC.pdf

Claxton, G., Craft, A. and Gardner, H. (2008). Concluding thoughts: Good thinking - education for wise creativity. In creativity, wisdom and trusteeship. Exploring the role of education, edited by anna craft, howard gardner, and guy claxton. Corwin Press: Thousand Oaks. 168-76.

Cochrane, P. and Cockett, M. (2007). Building a creative school: A dynamic approach to school development. Stoke-on-Trent: Trentham.

Cochrane, P., Craft, A. and Jefferey, G. (2008). Mixed messages or permissions and opportunities? Reflections on current policy perspectives on creativity in education. In creative learning, edited by julian sefton-green. Creative Partnerships: London. 27-39.

Corazza, G. E. (2016). Potential originality and effectiveness: The dynamic definition of creativity. Creativity Research Journal, 28(3): 258-67. 
Corbin, J. (2009). Taking an analytic journey. In developing grounded theory. The second generation, edited by janice morse, phyllis stern, juliet corbin, barbara bowers, kathy charmaz, and adele e. Clarke. Left Coast Press: Walnut Creek, CA. 35-530.

Corbin, J. and Strauss, A. (1990). Grounded theory research: Procedures, canons, and evaluative criteria. Qualitative Sociology, 13(1): 3-21.

Craft, A. (2000). Teaching creativity: Philosophy and practice. Routledge: New York.

Craft, A. (2003). The limits to creativity in education: Dilemmas for the educator. British Journal of Educational Studies, 51(2): 113-27. Available: http://www.jstor.org/stable/3122416

Craft, A. (2005). Creativity in Schools: tensions and dilemmas. Routledge: London.

Cranton, P. (2000). Individual differences and transformative learning. In learning as transformation: Critical perspectives on a theory in progress, edited by jack mezirow and associates. Jossey-Bass: San Francisco, CA,. 181-204.

Cremin, T. (2009). Creative teachers and creative teaching. In creativity in primary education, edited by anthony wilson. Learning Matters Ltd: Exeter. 36-46.

Cremin, T., Burnard, P. and Craft, A. (2006). Pedagogy and possibility thinking in the early years. International Journal of Thinking Skills and Creativity, 1: 108-19. Available: https://doi.org/10.1016/j.tsc.2006.07.001

Danvers, J. (2003). Towards a radical pedagogy: Provisional notes on learning and teaching in art and design. International Journal of Art and Design Education, 22(1): 47-57. Available: https://doi.org/10.1111/1468$\underline{5949.00338}$

Dirkes, A. M. (1978). The role of divergent production in the learning process. American Psychologist, 33: 815-20. Available: http://dx.doi.org/10.1037/0003-066X.33.9.815

Fasko, D., 2006. "Creative thinking and reasoning: Can you have one without the other?" In Creativity and reason in cognitive development, edited by James Kaufman C., and John Baer. New York, NY: Cambridge University Press. pp. 159-76.

Ferrari, A., Cachia, R. and Punie, Y. (2009). Innovation and creativity in education and training in the eu member states: Fostering creative learning and supporting innovative teaching. Office for Official Publications of the European Communities: Luxembourg. http://www.jrc.ec.europa.eu/

Friedel, C. and Rudd, R., 2005. "Creative thinking and learning styles in undergraduate agriculture students." In National AAAE Research Conference. pp. 199-211.

Gandini, L., Hill, L., Cadwell, L. and Schwall, C. (2005). In the spirit of the studio: Learning from the atelier of reggio emilia. Teachers' College Press: New York.

Halsey, K., Jones, M. and Lord, P. (2006). What works in stimulating creativity amongst socially excluded young people. National Foundation for Educational Research: NFER.

Jeffrey, B. (2006). Creative teaching and learning: Towards a common discourse and practice. Cambridge Journal of Education, 36(3): 399-414. Available: http://dx.doi.org/doi:10.1080/03057640600866015

Jeffrey, B. and Craft, A. (2004). Teaching creatively and teaching for creativity: Distinctions and relationships. Educational Studies, 30(1): 77-87. Available: https://doi.org/10.1080/0305569032000159750

Jensen, E. (1995). Brain-based learning. The Brain Store: San Diego.

Jónsdóttir, S. R. (2017). Narratives of creativity: How eight teachers on four school levels integrate creativity into teaching and learning. Thinking Skills and Creativity, 24(1): 127-39. Available: https://doi.org/10.1016/j.tsc.2017.02.008

Kleiman, P. (2008). Towards transformation: Conceptions of creativity in higher education. Innovation in Education and Teaching International, 45(3): 209-17.

LeCompte, M. D. and Preissle, J. (1993). Ethnography and qualitative design in educational research. CA: Academic Press: San Diego.

Lewis, T. (2005). Creativity: A framework for the design/problem solving discourse in technology education. Journal of Technology Education, 17(1): 35-52.

Lin, Y. S. (2011). Fostering creativity through education-a conceptual framework of creative pedagogy. Creative Education, 2(3): 149-55.

Morais, M. F. and Azevedo, I. (2011). What is a creative teacher and what is a creative pupil? Perceptions of teachers. Procedia-Social and Behavioral Sciences, 12: 330-39.

O'Sullivan, E. (2002). Expanding the boundaries of transformative learning. Palgrave: New York.

Patton, M. Q. (2015). Qualitative research and evaluation methods: Integrating theory and practice. Sage: Thousand Oaks, CA.

Piaget, J. (1962). Play, dreams, and imitation in childhood. W.W. Norton and Company, Inc: New York.

Plucker, J. A., Beghetto, R. A. and Dow, G. T. (2004). Why isn't creativity more important to educational psychologists? Potential, pitfalls, and future directions in creativity research. Educational Psychologist, 39(2): 83-96.

Robson, C. and McCartan, K. (2016). Real world research. 4th ednWiley.

Runco, M. A. (2008). Creativity and education. New Horizons in Education, 56(1): 96-104.

Runco, M. A. and Jaeger, G. J. (2012). The standard definition of creativity. Creativity Research Journal, 24(1): 9296.

Ruscio, A. M. and Amabile, T. M. (1999). Effect of instructional style on problem-solving creativity. Creativity Research Journal, 12(4): 251-66. 
Sefton-Green, J. (2008). From learning to creative learning: Concepts and traditions. In creative learning, edited by julian sefton-green. Creative Partnerships: London.

Sinnott, J. D., 1998. "Creativity and postformal thought: Why the last stage is the creative stage." In In Creativity and successful aging: theoretical and empirical approaches, edited by Carolyne E. Adams-Price. New York: Springer. pp. 43-72.

Strauss, A. and Corbin, J. (1990). Basics of qualitative research. CA: Sage: Thousand Oaks.

Torrance, P. E. (1977). Creativity in the classroom. National Education Association: Washington, DC.

Trana, T. L., Ho, T. N., Mackenzie, S. V. and Led, L. K. (2017). Developing assessment criteria of a lesson for creativity to promote teaching for creativity. Thinking Skills and Creativity, 25: 10-26. Available: https://doi.org/10.1016/j.tsc.2017.05.006

Vygotsky, L.-S. (2004). Imagination and creativity in childhood. Journal of Russian \& East European Psychology, 42(1): 7-97.

Williamson, P. K. (2011). The creative problem solving skills of arts and science students-the two cultures debate revisited. Thinking Skills and Creativity, 6(1): 31-43. Available: https://doi.org/10.1016/j.tsc.2010.08.001 